\title{
The Quandary of a Healthy (Child) Sibling Stem Cell Donor
}

\begin{abstract}
Feelings of abandonment in a healthy (child) sibling donor (HSD) merit ethical consideration; more so, when he is needed to undergo a minimally risky, yet painful, procedure of stem cell donation (SCD) for the benefit of his ill sibling (child suffering from blood cancer). The varied feelings of the HSD undergoing SCD procedure are being presented in the form of a poem.
\end{abstract}

Keywords: Clinical ethics, matched sibling donor, pediatric cancer patient, stem cell transplantation patient

When safeguards are no more in place, Leaving all three of us feeling vulnerable and outpaced....

When salutations have lost their hold and emotions are raging high,

Left only to the mercy of chance, we await a miraculous embrace...

Although ethically complex and emotionally intriguing,

Being your donor sibling is truly "overwhelming"....

Believe me! It will go a long way to improve our bond,

My heart feels deeply compelled, to enable you "happily" live long...

Have faith in me, Oh kin! 'Cause I am determined to help you,

Hold your vehement outcry, but a bit long...

The sun shall dawn once more on this dismal night,

And bring us hope, yet again to stay strong ${ }^{[1]}$..

Propelling myself ahead, by the love for you,

Here I am, donating my stem cells anew ${ }^{[2]} \ldots$

Just a few moments ago, I saw mom's heart shatter into pieces like glass,

And heard her crying aloud, "feeling sad; feeling blue"...

Move close to me, my brother, come near,

'Cause I wish to whisper something in your ear...

This is an open access journal, and articles are distributed under the terms of the Creative Commons Attribution-NonCommercial-ShareAlike 4.0 License, which allows others to remix, tweak, and build upon the work non-commercially, as long as appropriate credit is given and the new creations are licensed under the identical terms.

For reprints contact: WKHLRPMedknow_reprints@wolterskluwer.com
At first, I imagined I was "apparently" abandoned by her,

Mom's love for me seemed, as if it had entirely disappeared...

With "waves of rejection," I felt restless with a qualm,

Throwing me into a quandary, that wouldn't let me stay calm...

I thought "sickness" was a blessing and "being healthy" a heinous crime,

Luckily, "motivation to help you" became my healing balm...

My fondness for you, merits bearing a little pain,

Its minuscule, as of now, against so much more to gain...

As your donor sibling, I'd be better off in a joyous family of us three,

Than in a distressed one, if we were to lose you in vain.

\section{Acknowledgment}

The author would like to gratefully thank Mr. Samrat Chauhan, Senior Consultant and Facilitator, Pegasus Academy, Dehradun, for his review of the poem and helpful suggestions.

Financial support and sponsorship

Nil.

\section{Conflicts of interest}

There are no conflicts of interest.

\section{References}

1. Raturi M. Celebrating his second chance at life again. Indian $\mathrm{J}$ Med Paediatr Oncol 2020;41:400.

2. Raturi M. Saviour sibling. Indian $\mathrm{J}$ Med Paediatr Oncol 2020;41:238.

How to cite this article: Raturi M. The quandary of a healthy (child) sibling stem cell donor. Indian J Med Paediatr Oncol 2020;41:562.

\section{Manish Raturi}

Department of

Immunohematology and Blood

Transfusion, Himalayan Institute

of Medical Sciences, Swami

Rama Himalayan University,

Dehradun, Uttarakhand, India
Submitted: 27-May-2020 Accepted in Revised Form: 10-Jun-2020

Published: 29-Aug-2020

Address for correspondence: Dr. Manish Raturi,

Department of

Immunohematology and Blood Transfusion, Himalayan Institute of Medical Sciences, Swami Rama Himalayan University, Swami Ram Nagar, Jolly Grant, Dehradun - 248016 , Uttarakhand, India.

E-mail: manishraturi@srhu. edu.in

Access this article online

Website: www.ijmpo.org

DOI: 10.4103/jijmpo.ijmpo_261_20

Quick Response Code:

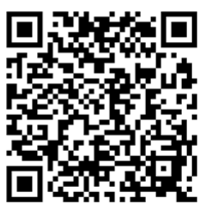

